\author{
Magdalena GRAF \\ Uniwersytet im Adama Mickiewicz w Poznaniu \\ m.graf@amu.edu.pl \\ http://orcid.org/0000-0002-0540-355X
}

\title{
(NIE)WINNE ROZWAŻANIA O AROMACIE WINA (NA MARGINESIE ENOLOGICZNYCH FELIETONÓW MARKA BIEŃCZYKA)
}

\begin{abstract}
„Gdy mówimy o winie, najczęściej zwracamy się [...] ku przeszłości: tyle w nim tajemnicy chwil, które minęły, tyle zagadek starości, tyle czasu, który nie zgubił się i nie zmarnował [...]. Ale w swej istocie wino, jak myślę, otwiera w nas i przed nami zwłaszcza ten inny wymiar czasu - czas przyszły. Jeśli istnieje cudowne działanie wina, to polega ono właśnie na tym."
\end{abstract}

[M. Bieńczyk, Kroniki wina]

Zbigniew Herbert, w tomie Barbarzyńca w ogrodzie stwierdził: „Opis wina jest trudniejszy niż opis katedry". (Herbert 1996: 69) Co zatem robić, żeby nie stać się owym ogrodowym barbarzyńcą? Marek Bieńczyk radzi: „Zamiast czytać podręczniki do degustacji, wystarczy sięgnąć, rzecz jasna, po Herberta." (NKW, 161) Nie jest to jednak takie proste, a współcześnie, wobec wciąż rozwijającego się dyskursu enologicznego, wręcz niewystarczające. Podjęcie tego tematu nastręcza bowiem kilka problemów, zarówno wewnątrz, jak i pozajęzykowych. „Początkującym słownictwo winiarskie może wydawać się tajemniczym żargonem, chociaż stanowi ono dosyć spójną całość" pisze na swojej stronie internetowej autor Degustacyjnego słownika winiarskiego, dodając: „By cieszyć się winem, docenić jego walory smakowe i zapachowe, a przede wszystkim towarzyskie, warto chociaż $w$ ograniczonym zakresie poznać jego język"1 [podkr. M.G.].

1 Wiktor Zastróżny http://wiktorzastrozny.com/. Nie jest to jedyne opracowanie terminologii enologicznej, jest jednak przez znawców, m.in. M. Bieńczyka, uznawane za najlepszą tego typu publikację w Polsce. 
O tym, że jest to zadanie dla wytrwałych, świadczyć może problem z oznaczaniem podstawowych terminów, jak choćby pojęcia aromat. Krystyna Pisarkowa sytuuje to określenie w grupie leksemów nazywających wydzielanie zapachów przyjemnych. (Pisarkowa 1972: 330) Stosowana w polszczyźnie, najogólniejsza definicja określa go jako przyjemny zapach, woń roślinną (SJP). Zasadniczo brak tego pojęcia w innych słownikach języka polskiego, a w tekstach literackich uzupełnia go konkretyzujący leksem (np. aromat wanilii/waniliowy). Zjawisko to omawia Marian Bugajski (Bugajski 2004: 113), za przyczyny trudności z jednoznacznym systematyzowaniem zapachów w polszczyźnie i związanych z tym problemów terminologicznych uznając m.in. brak jednolitych kryteriów typologizujących, subiektywność percepcji zapachowej oraz swoistą „ulotność" woni ${ }^{2}$.

W socjolekcie enologicznym aromat jest zazwyczaj uznawany za synonim zapachu wina i definiowany w następujący sposób: „pojęcie opisujące substancje zapachowe, które trafiają do wina za sprawą winogron (głównie ze skórki i strefy tuż pod nią). Różne szczepy charakteryzują się odmienną intensywnością zawartych w nich związków aromatycznych, co bezpośrednio przekłada się na ich późniejszą wyczuwalność w winie. Pojęcie aromatu bywa mylone $\mathrm{z}$ bukietem, który jest zespołem zapachów wtórnych w winie, nabytych w procesie fermentacji i dojrzewania. Bukiet

2 Co interesujące, terminowi aromat jest w przywoływanej pracy poświęcony niewielki passus, zaś w pomieszczonym na końcu opracowania słowniku leksem ten funkcjonuje jako nadrzędnik konstrukcji z rzeczownikiem lub przymiotnikiem. (Bugajski 2004: 265). Podobnie złożony charakter może mieć językowe ujęcie zapachu perfum. W tym przypadku, w perfumeryjnym opisie woni, poza terminem aromat pojawiają się też takie określania, jak akord (kilka nut zapachowych „zgranych" razem, np. akord szyprowy to nuty bergamotki, paczuli i mchu dębowego) i absolut (czyli esencja zapachu). Sam proces tworzenia zapachu perfum wyzyskuje - oprócz zmysłu węchu - także pamięć, zdolność kojarzenia, wyobraźnię i emocje. Przydatną cechą jest też talent językowy. Zob. wywiad z Martą Siembab, Senselierką. Źródło: http://kobieta.gazeta.pl/kobieta/1,107881,129402 20,senselierka-jak-zostalam-jedyna-w-polsce-specjalistka-od-zapachow.html. W przemyśle perfumeryjnym - choć nie jest to obowiązującym zwyczajem - o zapachu i związanych z nim skojarzeniach informować może nazwa. Jak zauważa D. Saniewska, „Perfumy to specyficzny rodzaj zapachu, czyli [...] odczuwalnej powonieniem właściwości jakiejś substancji. W przypadku perfum właściwości te wynikają z odpowiednio dobranej kompozycji substancji zapachowych w roztworze alkoholowym". Zob. D. Saniewska, Klejnot na szyi kobiety. O nazwach damskich perfum, http://repozytorium.uwb.edu.pl/jspui/bitstream/ 11320/1071/1/BAJ_12_Saniewska.pdf. Warto też choć wspomnieć, że w przemyśle perfumeryjnym wykorzystywane są ustalenia z zakresu psychologii zapachu - wszystko to ukazuje, że $w$ tej dziedzinie indywidualizacja dotyczy procesu percepcji zapachu, a nie (jak w enologii) jego ostatecznego opisu ( zwłaszcza, że złożoność aromatu wina wynika m.in. z powiązania doznań zapachowych, smakowych i taktylnych). 
z czasem zazwyczaj się uszlachetnia, aromaty natomiast nieco przygasają, ale stają się zarazem bardziej złożone" ${ }^{3}$. Pozornie wszystko jest oczywiste, ale już na oficjalnej stronie internetowej Stowarzyszenia Winiarzy i Miodosytników Polskich, termin aromat wina charakteryzowany jest jako „zapach, który czujemy kiedy wino już jest w ustach żeby jakoś odróżnić to coś od zapachu który czujemy nosem [podkr. M.G.] przed nabraniem wina do ust. Zapachy [...] mogą być pierwotne (pochodzące z odmian), wtórne (powstające podczas fermentacji) i trzeciorzędowe (zwane bukietem) powstające w trakcie dojrzewania" ${ }^{4}$. Niewiele tylko różniącą sie definicję ma w enologicznym leksykonie - pozornie odmienny semantycznie - termin posmak: „suma wrażeń odczuwanych przez usta i nos; zapach jest odczuwany nosem, smak nosem i tylną częścią gardła; posmak to smak $\mathrm{i}$ aromat pozostający $\mathrm{w}$ ustach po przełknięciu wina; najbliższe $\mathrm{w}$ języku polskim określenie na kombinację wrażeń węchowych (nos) i smakowych (usta), czyli aromatu i smaku; niektórzy określają to jako wewnętrzny bukiet, jaki czasami pozostaje w gardle i tylnej części nosa po przełknięciu wina; może być wrażeniem zarówno przyjemnym, jak i nieprzyjemnym; natężenie i czas trwania p. określane bywa długością smaku, który może być wskaźnikiem jakości wina i jego dobrej harmonii; p. może być: szorstki nieprzyjazny, surowy, chropawy, cierpki, gorący, miękki, krótki, długi, gładki, taninowy, maślany, gorzki, dębowy, korzenny, może też go nie być wcale" 5 .

Wciąż rozwijający się leksykon winiarski (wśród znawców pojawiają się wręcz głosy, by to filologowie, także poloniści, sporządzili „normatywny" słownik pojęć 6 ) obejmuje znaczną grupę leksemów obcych, szczególnie galicyzmów - obecnych zarówno w postaci oryginalnej, jak i przy-

\footnotetext{
3 http://www.owinie.info/slownik-pojec/

4 http://wino.org.pl/old-swimp/content/view/

5 http://festus.pl/?s=posmak\&category_slug=slownik
}

6 W notce informującej o zawartości leksykonu W. Zastróżnego czytamy: „W słowniku znajdą Państwo wiele określeń występujących równolegle, które są bliskoznaczne, ale zwykle wyrażają nieznaczne różnice w intensywności i charakterze danej cechy. «Winny» (vineux) w języku francuskim może oznaczać kolor wina, właściwie wina czerwonego, coś, co pachnie lub smakuje jak wino, albo wino mocne, silne, $\mathrm{z}$ wigorem. Francuzi o młodym (primeur), orzeźwiającym, zaspokajającym pragnienie winie mówią canaille, co oznacza mniej więcej łotrowski, szelmowski. O mniej lub bardziej mocnym winie, ale zbyt ciężkim, mawiają corsage, cuisse (czyli, że ma biust lub uda). Byłoby pięknie dla przyszłych smakoszy i degustatorów, gdyby poloniści oraz romaniści pokusili się kiedyś o stworzenie normatywnego słownika winiarskiego." http://wiktorzastrozny.com/ [dostęp: 30.06.2016]. 
swojonej czy też tłumaczonej (częstokroć, z braku pewności, czy dany termin został przetłumaczony poprawnie, pojawiają się formy synonimiczne, co pośrednio wskazuje na brak stabilizacji tej leksyki). Zasób ten jest ciągle uzupełniany, co wiąże się m.in. z coraz większym kręgiem jego użytkowników: „Gdyby chcieli się państwo wykazać znajomością wina w jakimś snobistycznym towarzystwie znawców - podpowiada M. Bieńczyk - radziłbym używać słowa „mineralność”. [...] „Mineralność” nie należy bynajmniej do odwiecznego słownika degustatorów. [...] Wymyślił je ponoć francuski dziennikarz Michel Dovaz, który podczas pewnego przyjęcia nie bardzo wiedział, jak zdefiniować testowane właśnie wina, i na język przyszło mu niewinne to właśnie słowo: mineralne! Co ono jednak dokładnie znaczy, Pan Bóg raczy wiedzieć" (NKW, 25). Innym terminem ilustrującym stałe poszerzanie się enologicznego leksykonu jest określenie garażowe wina - używane od niedawna, określające wina wysokiej jakości, zazwyczaj bardzo drogie, produkowane przez małych producentów i w niewielkich ilościach. Są to wina, które charakteryzuje zazwyczaj duży indywidualizm i brak powtarzalności, w przeciwieństwie do tych wytwarzanych przez dużych producentów o uznanej już renomie, starających się wprowadzać na rynek wina charakteryzujące się zbliżonymi walorami degustacyjnymi ${ }^{7}$.

Jednak elementem $\mathrm{w}$ istotnym stopniu wpływającym na enologiczny dyskurs jest też perspektywa odbiorcy - tłumacza, filologa, znawcy wina czy po prostu okazjonalnego degustatora. Zjawisko to postaram się pokrótce zilustrować dwoma przykładami. Rozwijający się rynek przyniósł znaczny wzrost publikacji dotyczących historii, produkcji i kultury picia wina, a w początkowym okresie były to przede wszystkim tłumaczenia wydawnictw obcych. O niebagatelnej roli tłumacza tych tekstów pisze Anna Bochnakowa, zdaniem której tłumacz jest nie tylko pośrednikiem między dwoma językami (czy w szerszym sensie: kulturami), ale też niejednokrotnie staje się twórcą nowej terminologii, zwłaszcza gdy translacja dotyczy zjawisk nieznanych lub mało rozpoznanych. (Bochniakowa 2002) Przywoływany artykuł zawiera również interesującą ocenę trafności rodzimych ekwiwalentów francuskich leksemów, przekonuje też o poczuciu „nowości” tego typu określeń, o czym świadczyć może fakt, iż niektóre z nich, np. krągłość, wyrafinowanie, gęstość, choć powszechnie już stoso-

7 Jednym z najpopularniejszych i najbardziej uznanych producentów win garażowych jest - według M. Bieńczyka - znany francuski aktor Gerard Depardieu. 
wane w enologicznym dyskursie, autorka artykułu zapisuje w cudzysłowie. Warto jednak zauważyć, że pozostawienie terminu $\mathrm{w}$ oryginalnym kształcie związane jest najczęściej z brakiem odpowiedniego ekwiwalentu, brakiem wynikającym z odmiennego poziomu kultury winiarskiej w Polsce, co skutkuje koniecznością zastosowania szerszego opisu nazywanego zjawiska. Dotyczy to choćby takich pojęć, jak np. agrafe (fr.) - koszyk druciany przytrzymujący korek od szampana; en primeur (fr.) - termin oznaczający możliwość zakupu wina przed jego zabutelkowaniem, na podstawie próbek $z$ beczek ocenianych $w$ następnym roku po zbiorach; barrique - (najczęściej) dębowa beczka pochodząca z Bordeaux o pojemności wynoszącej 2251 - istotna w procesie wytwarzania wina, gdyż potrafi (szczególnie, gdy jest nowa) wyraźnie zmienić kształt i smak wina.

Co na ten temat twierdzi Marek Bieńczyk? W felietonie Wino i imiona jednoznacznie stwierdza, że użytkownicy (zarówno wina, jak i języka, w tym także językoznawcy) nie zawsze mają świadomość lub potrafią poprawnie posługiwać się nie tylko skomplikowaną fachową terminologią, ale również - wydawałoby się znacznie łatwiejszą - ortografią:

Istnieją podobno precyzyjne reguły dotyczące należytego stawiania liter $\mathrm{w}$ winiarskiej literaturze, raz dużych, raz małych, ale ani $w$ języku rodzimym, ani w językach obcych nie udało mi się trafić na ich prawdziwie konsekwentne stosowanie. Pisać nazwę wina dużą czy małą, honorować château majuskułą czy nie? Co robić, gdy mamy do czynienia z całym regionem, co począć z jedną apelacją [...] i jak do licha się zachować, gdy w grę wchodzi szczególna i niepowtarzalna nazwa jednej tylko parcelki? I w ogóle nie oszaleć i poprawność pisowni uszanować, gdy nazwa wina okazuje się nazwą apelacji, która jednak sprowadza się do nazwy jednej parceli?

Ta cała złożoność problemu oddaje złożoność bytu wina, a bytu jeszcze nikt ortograficznie nie umocował. [...] jak można Haut-Brion pisać małą [literą - M.G.], skoro pije się je na klęczkach?" (NKW, 7).

Ale leksykon winiarski jest o wiele bardziej skomplikowany, gdy przygląda się mu ktoś, kto nie jest znawcą tej materii, co ilustrują wybrane tezy tekstu Katarzyny Skrzypczak, która na opisy towarzyszące degustacji wina spojrzała z perspektywy kognitywnej. (Skrzypczak 2013) Przyjęty przez autorkę sposób mówienia o leksyce enologicznej ukazuje presuponowaną potrzebę jej „odprofesjonalizowania”. Czytamy tu m.in.: „Specjaliści wina posługują sie fachowym słownictwem [...] im większa wiedza o winie, tym bardziej zaawansowane słownictwo, którym się posługują. Czytając opisy win czy studiując słowniki terminów winiarzy, zauważyć można terminy określające smak, wykraczające jednak poza 
kanon [...] pięciu smaków. Powodem owego wykraczania [...] jest fakt, że smakujący wino odczuwa jego prawdziwy [sic! - M.G.] smak, jednak opisanie go [...] staje się wysokiej rangi poprzeczką, dlatego, aby przybliżyć czytelnikowi prawdziwy smak, zapach i teksturę wina stosowane są w języku winiarskim metafory i metonimie" (Skrzypczak 2013: 101-102). Ostatnie zdanie wskazuje na niezwykle interesującą cechę, czyli silną metaforyzację tego dyskursu, tym silniej odczuwaną, im mniejsza znajomość stosowanej terminologii. Wydaje się więc, że koniecznie należy rozgraniczyć różne typy dyskursu winiarskiego, uzależnione od odbiorcy i poziomu jego kompetencji. Bowiem przywoływane przez autorkę tekstu terminy typu: aksamitne, miękkie, szorstkie wino, pozwalające jej zbudować uogólnioną metaforę typu: „wino to tkanina”, nie są, jak wskazuje badaczka, próbą wyjaśnienia czy choćby przybliżenia laikom prawdziwego smaku wina (bo też jak wyjaśnić smak wina zielonego, szorstkiego, okragłego czy tłustego?). Opisanie wrażeń towarzyszących degustacji a związanych z jedną, wybraną cechą, jest zadaniem znacznie bardziej złożonym, co ilustruje choćby poniższa definicja pojęcia [wino] agresywne zamieszczona na jednym z portali winiarskich, charakterem przypominająca definicję synonimiczną, potwierdzająca jednak rozpoznanie o niemożności zastąpienia fachowych terminów ich synonimami czy całkowitej rezygnacji z profesjonalnej leksyki:

AGRESYWNE acerbe | aggressive | agressif | mordant: niedojrzałe, surowe, niezrównoważone; wina przesadnie żywe, nieco szorstkie, drażniące podniebienie, zwykle z powodu dużej zawartości kwasów lub tanin (często jednych i drugich), także alkoholu; silnie i nieprzyjemnie atakujące błonę śluzową; młode wina na ogół są dość agresywne, ale po przebywaniu przez pewien czas $\mathrm{w}$ butelce zwykle stają się bardziej okrągłe, łagodnieją; agresywne są często taniny w młodych, czerwonych winach, które z czasem ulegają polimeryzacji i łagodnieją; a. bywają także wina starsze, które z różnych powodów pozostają niedojrzałe (np. gdy do wina dodano zbyt wiele wiórów dębowych); wysoka kwasowość podkreśla taninowy charakter wina; w jakimś stopniu synonim wina rustykalnego, zielonego, przeciwieństwo wina miękkiego i gładkiego; określenie zwykle negatywne ${ }^{8}$.

\footnotetext{
8 http://festus.pl/slownik/. O tym, że nie musi to być jednoznacznie negatywny termin świadczy definicja jego antonimu, czyli określenia: pieszczotliwe: „caressant | caressing | cherishing; wino stonowane, rozpływające się w ustach, bez ostrości, agresywnych tanin, chropowatości; określenie czasami ironiczne, ponieważ nie przesądza o jakości wina". O metaforze agresywne wino K. Skrzypczak pisze: „jest to wino więc jakoby zaskakujące nas, tak jak człowiek siłą czy słowem, swoim niemiłym smakiem odczuwalnym na podniebieniu". K. Skrzypczak, op. cit., s. 104.
} 
Dostrzeżony tu problem wynika z faktu, iż w winnym dyskursie nie charakteryzuje się po prostu smaku, co więcej, wrażenia smakowe są uszczegółowiane z perspektywy oceny określonej właściwości wina. W tym przypadku nasze - bardzo powierzchowne - rozróżnianie pięciu smaków jest całkowicie nieprzydatne. Istotną rolę odgrywa tu bowiem węch, który jest wielokrotnie bardziej wrażliwy na stężenie cząsteczek chemicznych niż smak - oznacza to, że pozbawione doznań węchowych wrażenia smakowe są bardzo słabe lub wręcz nieodczuwalne ${ }^{9}$ - zatem to węch okazuje się zmysłem dominującym przy okazji wszelkich degustacji, w tym również degustacji wina, stąd poświęca się mu najwięcej uwagi. Nie można też pominąć jeszcze jednego zmysłu - przy próbowaniu trunku niezmiernie ważny jest dotyk, który pozwala poczuć konsystencję, czyli budowę wina.

Owe wrażenia zapachowo-smakowo-dotykowe są dodatkowo uzależnione od wielu innych czynników, m.in. szczepu winogron (lub ich kupażu), klasy wina, jego wieku, pochodzenia, leżakowania, transportu itd. Co istotne, wbrew ustaleniom Linneusza, który wymienia wino wśród woni eterycznych (Pisarkowa 1972: 331, Bugajski 2004: 53-54), wino nie ma swojego specyficznego zapachu, ale emituje min. 350 różnych woni. Jak te doznania opisać? Marek Bieńczyk radzi, by charakteryzując usta wina zwrócić się ku architekturze: oto bowiem

Większości artykułów poświęconych opisowi smakowych doznań towarzyszą zdjęcia sklepień, na ogół drewnianych, z dużą ilością gontów, desek, poprzeczek itd. Mają one unaocznić, że wino, podobnie jak wielkie budowle, ma swój szkielet konstrukcyjny, swój kościec, swoją „strukturę" (KW, 74-75).

Ów szkielet opiera się na różnych typach woni. Zapachy pierwotne (podstawowe), charakteryzujące młode wina, zależne są od szczepu winogron i stopnia ich dojrzałości. W czasie dojrzewania, w winie pojawiają się tzw. zapachy wtórne, zależne od sposobu maceracji i winifikacji, zaś stare wina posiadają to, co jest nazywane bukietem wina (zapachy trzeciorzędne), a ponieważ ma on złożony charakter, wytrawny znawca powinien odczuwać jego odcienie przypominające różnego typu

\footnotetext{
9 Aktualne badania z zakresu nauk medycznych przekonują, że człowiek jest w stanie zidentyfikować, bagatela, ponad dziesięć tysięcy zapachów. Zob. E. Potargowicz, Węch niedoceniany zmysł człowieka, "Postępy Higieny i Medycyny Doświadczalnej” 2008, nr 62, s. 88, (online), [dostęp: 15.03.2014]. Dyskusję nad tym ile zapachów odczuwa człowiek zob. http://www.literatura.gildia.pl/tworcy/avery_gilbert/co_wnosi_nos_nauka_o_tym_co_nam -pachnie/fragment
} 
aromaty kwiatowe (fiołków, róży, jaśminu, tymianku, lawendy itp.), świeżych owoców (wiśni, malin, czarnych porzeczek, cytryn, pigwy itd.), roślin (świeżo skoszonej trawy, ściółki, torfu, paproci itp.), korzeni (wanilii, lukrecji, pieprzu, jałowca, gałki muszkatołowej, goździków), aromaty pochodzące z palenia różnych produktów i substancji (m.in. kawy, chleba, tytoniu, dymu, migdałów) oraz aromaty zwierzęce (jak piżmo, ambra, skóra, odchody). Co ciekawe, nawet stereotypowo negatywnie konotujące zapachy, w przypadku oceny wina są pozytywnie wartościowane dotyczy to np. zapachu benzyny, który jest niuansem zapachowym pożądanym w niektórych typach win. Pisze też o tym Bieńczyk, przyjmujący $\mathrm{w}$ tym momencie postawę konesera:

Winu towarzyszy więcej takich zapachów, pozornie odległych od wina jak księżyc od ziemi [...]. Wśród tych kuriozalnych aromatów mamy całą spiżarnię: czekoladę i kawę paloną (częstą $\mathrm{w}$ wielkich bordeaux, podobnie jak zapach innej używki - tabaki), świeże masło, chleb z piekarnika, drożdże, briosze, karmelki; mamy cały las przed nadejściem białego człowieka: mech, poszycie, korę, zgniłe liście, grzyby, trufle, skórę zwierzęcą [...] a nawet proszę się nie wzdrygać, efekt jest wspaniały - zwierzęce flaki; ponadto różne stany drzewa: spalonego, mokrego, węgiel drzewny (a także smołę częstą na przykład w bardzo już dojrzałym włoskim barolo); nie mogę też nie wspomnieć o aromatach odchodów, czyli, mówiąc wprost, łajna, które wiele Nosów odkrywa w burgundach (KW, 107).

W innym jednak miejscu, mając świadomość, iż jego czytelnikami są nie tylko profesjonalni degustatorzy, ale też np. słabo orientujący się w tej problematyce wielbiciele jego pisarstwa, stara się oswoić swoich odbiorców z zapachową specyfiką obcowania z dobrym gatunkowo winem:

"Nos Cyrana" - tak niekiedy mówi się o bukiecie win, które rozwijają długą, złożoną paletę zapachów. I, zarazem, taki powinien być nos degustatora czy zawodowego enologa [...]. Miałem niedawno okazję odbyć $\mathrm{z}$ takim znawcą (oceniał swe możliwości na 200 zapachów) spacer po mieście. Zachowywał się jak wyżeł na niewidzialnej smyczy; po prostu węszył nieustannie. [...] Kiedy tego dnia szliśmy do mnie na kolację, bałem się - co zrozumie każdy mieszkaniec Grochowa - wprowadzić go na moją klatkę schodową: wstyd zapewniony. - Kocie siki - powiedział oczywiście, od razu na parterze. - Dobry zapach, spotykany w białych winach. [...] Tak, honor mojej dzielnicy został uratowany przez [...] chemiczny wzór związku, dającego ów niezbywalny zapach; przy innej jego intensywności jest to też zapach czarnej porzeczki. Zapach ten, zwany pipi de chat, występuje niekiedy w winach wyprodukowanych ze szczepu sauvignon; przy bardzo udanych butelkach jego leciutka nuta wzbogaca zapach; staje się rzecz jasna wadą, gdy wino pachnie zbyt mocno warszawskimi schodami (KW, 106). 
Wymienione wyżej zapachy wina zwykle rozwijają się $\mathrm{w}$ określonym porządku: najpierw odczuwamy zapach kwiatów, potem owoców i roślin a później pozostałe, stąd wąchanie wina jest procesem - $\mathrm{w}$ terminologii winiarskiej mówi się zatem o pierwszym, drugim i trzecim nosie; co interesujące, w przypadku tego ostatniego wąchamy opróżniony kieliszek, gdyż cząsteczki zapachowe w starszych winach uwalniają się po dłuższym kontakcie $\mathrm{z}$ tlenem. W dyskursie winiarskim stosowane są też określone skróty pojęciowe, których rozwiązanie znów zależy od czytelnika i poziomu jego kompetencji. Stosuje się np. określenie czarne owoce to termin degustacyjny opisujący smak i aromat wina przywołujący aromat jagód, jeżyn, wiśni, czarnych porzeczek - jak widać, są wśród nich owoce, które uznalibyśmy za czerwone. Przykłady tego typu terminów można mnożyć, a to sprawia, że:

w tym smakowaniu wszystko takie trudne - pisze M. Bieńczyk - a dostrzec i obliczyć pawi ogon jest najwyższą sztuką w degustacji, bardziej skomplikowaną niż ocena barwy, bukietu i budowy wina, i wciąż się jej nieudolnie uczę (KW, 15).

Trzeba jednak przyznać, że jak na nieudolnego adepta sztuki degustowania i opisywania wina autor poczyna sobie nad wyraz dobrze. Może więc te słowa to po prostu przesadna skromność lub oczywiste stwierdzenie faktu, że socjolekt winiarski to nie tylko fachowa terminologia, ale również subiektywne doznania i indywidualne cechy stylu, którymi doznania te można oddać. Bo, jak dodaje w dalszej części Kronik wina: "zawodowy dyskurs o winie szuka własnej, odrębnej, oryginalnej formy" i dopowiada, że dyskurs ten

musi pozostać $\mathrm{w}$ jakiejś mierze techniczny - tego się od nich [degustatorów - M.G.] oczekuje; oczekuje się, że określą barwę, wyłapią wady wina, obliczą, kiedy osiągnie dojrzałość i co się na starość zmieni [...]. Jest to zarazem język ludzi wplątanych w historię miłosną i szukających, jak każdy zakochany, form wyrazu dla [...] swego uczucia. Dlatego dyskurs degustacyjny co krok przełamuje swą techniczną konkretność i dobiera słów, metafor, składni i dykcji, które mówiąc o osobowości wina, wyrażają kondycję degustatora [...] (KW, 18-19).

Nieprzypadkowo więc pisarz wybiera felieton jako ten gatunek tekstu, który w najdoskonalszy sposób opowie nie tyle o winie, ile o Marku Bieńczyku delektującym się kieliszkiem tego trunku. Bo to właśnie postać autora jest głównym tematem tych tekstów, co zresztą jest jednym 
z wyznaczników gatunkowych felietonu. Warto w tym miejscu zaznaczyć, że można też pisać o samym winie - wymaga to jednak zmiany autora tekstów, a rozpoznanie to potwierdza choćby lektura enologicznych felietonów Jerzego Mazgaja pt. Moje wina publikowanych w Newsweeku ${ }^{10}$. Mimo że felieton jako gatunek tekstu ma już obszerną bibliografię, zajmujący się tym zagadnieniem badacze wciąż dyskutują na temat jego prymarnych i peryferyjnych cech gatunkowych ${ }^{11}$. Piotr Stasiński wskazuje na służącą indywidualizacji nieoficjalność wywodu, w jeszcze większym stopniu pozycję i idiostyl autora podkreśla Ewa Sławkowa (Barańska-Szmitko 2014: 212-213). Maria Wojtak kieruje uwagę na zdolność dyfuzji wzorców innych gatunków, zarówno publicystycznych, jaki i literackich czy użytkowych oraz na wyzyskanie zjawiska stylizacji; podkreśla też, że obok perspektywy autorskiej istotną rolę odgrywa aktualność podejmowanej tematyki, a cechy te na dalszy plan usuwają właściwości strukturalne felietonu (Wojtak 2004a: 212; Wojtak 2004: 276). Lektura opracowań teoretycznych przekonuje, że aktualność jest wręcz gatunkowym imperatywem. Tymczasem w odniesieniu do tekstów M. Bieńczyka aktualność tę rozumieć można w połączeniu z drugą cechą felietonu - jego subiektywnością: oto pisarz komentuje ten aspekt rzeczywistości, który jest niezmiennie aktualny w jego własnym mikroświecie. Stąd daleko posunięta indywidualizacja - obserwowana zarówno w płaszczyźnie tematycznej, jak i na poziomie stylu. Bo - jak przekonująco stwierdza M. Wojtak, felieton "to cały gatunkowy kosmos [który - M.G.] wymyka się definicjom i uogólnieniom”. Dodaje też: „jest gatunkiem opartym na paradoksach [stąd - M.G.] niemal każdą cechę felietonu można zanegować, znajdując przykłady realizacji cechy przeciwnej" (Wojtak 2008: 109-110). Konieczne odniesienie do bieżących spraw jest w tek-

10 Przykładowo, pisząc o Aromo Private Reserve Syrah, autor w kilku słowach opisuje kraj jego pochodzenia i chilijskie tradycje winiarskie, by w drugiej części felietonu uwagę skupić już na szczepie, z którego jest wytwarzane i na degustowanym winie informując m.in. o jego producencie. Charakterystycznym chwytem jest tu stosowanie liczby mnogiej, co podkreśla kontakt z odbiorcą (np. „My spróbujemy wina z doliny Maule”). Końcową część tekstu stanowi już charakterystyka wina, np. „ma charakterystyczny dla szczepu intensywny, wręcz fioletowy kolor. Pachnie ciemnymi owocami podrasowanymi delikatnie nutą pieprzu. Wyraziste taniny od razu zdradzają konkretny i pełnokrwisty charakter tego wina." „Newsweek”, nr 49, 2016.

11 Dyskusję nad cechami definicyjnymi tego gatunku szczegółowo i wyczerpująco referuje A. Barańska-Szmitko, w artykule: Możliwości i ograniczenia felietonu jako narzędzia kreowania wizerunku jego autora, "Acta Universitatis Lodziensis. Folia Litteraria Polonica”, 1(23)/2014, s. 211-227; toteż w swoim tekście rezygnuję z omawiania tego zagadnienia. 
stach M. Bieńczyka przedmiotem autorskiego konceptu - oto swoim felietonom pisarz nadaje tytuł Kroniki wina sugerując tym samym zarówno wysoką rangę podejmowanych zagadnień, jak i ich (pozorną) aktualność. Pozorną, gdyż kronika jako gatunek tekstu stanowi „chronologiczny zapis wymieniający ważniejsze wydarzenia z życia państwa, instytucji, organizacji itp. Niewyjaśniający ich związku przyczynowego" lub „stały przegląd wydarzeń bieżących” (SJP) - zatem w tym przypadku gatunkowe nawiązania zasadniczo wyczerpują się już na poziomie nazwy cyklu.

Cóż zatem możemy się dowiedzieć o winie smakowanym przez Marka Bieńczyka? Jak sam wskazuje w tytule jednego z felietonów, jest to nie tyle fachowy opis, ile Skarga zakochanego; co warto dodać: zakochanego filologa, który zdaje sobie sprawę, jakim problemem jest usystematyzowany opis win, ale też jest przekonany, że w opisie tym istotna jest nie „litera prawa”, ale intencja degustatora relacjonującego indywidualne doznania. Pisząc więc o sobie, powraca do sygnalizowanej wcześniej odniesieniami do twórczości Z. Herberta, architektonicznej metaforyki:

Mój domek nazywa się Medok i dobrze się w nim mieszka. Jeden pokój, ten większy, należy do caberneta i pachnie w nim czarną porzeczką, piwonią, niekiedy goździkami, kakao i papryką, a nawet skórą. Mniejszy pokój to posiadłość merlota i czuć w nim róże, mech, maliny, poziomki, czasem też piżmo i trufle (KW 42).

Wino emituje setki woni, ale nawet odczuwając określony zapach nie zawsze jesteśmy w stanie zwerbalizować nasze doznania, gdyż „droga” z narządu węchu do mózgu jest znacznie krótsza, niż w przypadku innych zmysłów, stąd mózg nie jest w stanie w tak krótkim czasie powiązać zapach $\mathrm{z}$ odpowiednim pojęciem. W konceptualizacji zapachów istotną rolę odgrywają też czynniki kulturowe, związane np. z preferowaniem lub unikaniem odpowiednich zapachów czy smaków - pisze o tym wyczerpująco Marian Bugajski (Bugajski 2004: 11-12, 32-37). Odnajdujemy to też $\mathrm{w}$ felietonach M. Bieńczyka, zwłaszcza w interesującym fragmencie dotyczącym konotacji uwarunkowanej geograficznie i kulturowo, ale też zależnej od subiektywnego doświadczenia. Oto pisząc o bardziej lub mniej „typowych" winnych aromatach, M. Bieńczyk zauważa, ze wprawdzie można ich nazwy odnaleźć w różnego typu tabelach i wykazach, w których jednak 
nie ma [...] miejsca dla bardzo oryginalnych określeń, których używają degustatorzy, chcąc wyrazić wyjątkową szczególność wdychanego aromatu. Najbardziej zapadło mi w pamięć określenie spotykane w opisie pomerola Château Pétru [...]: konfitura starego kawalera. Jak to do licha pachnie; co to do diaska jest? Kurz w kącie łazienki zmieszany z wodą kolonską „Wiarus"? Naczynia w zlewie po kolacji sprzed tygodnia? Zapomniana szprotka na talerzu pod nigdy nie otwieranym oknem? Szafka z butami otwarta na oścież? Czy po prostu dżem z leśnych owoców? (KW 107-108).

Ciekawe, rodzime odniesienia zapachowe pisarz podkreśla stosowanym w kronikach terminem regionalne podniebienie. Regionalność rozumie jednak bardzo szeroko, dowodząc, że Amerykanie lubią wina młode, Anglicy eleganckie, Francuzi zrównoważone a Polacy?

My z kraju sernika i buraków cukrowych? [...] Niestety, niestety! Jesteśmy pod względem wina czerwoną latarnią narodów, autobusem z napisem „,koniec". [...] Albowiem wedle wszelkich statystyk smakuje nam słodkie! [...] Niczego tak powszechnie polskie podniebienie nie toleruje, jak garści gorzkich garbników w winie czerwonym i smaku minerałów w winie białym [...]. Ostatni w Europie, najgorsi na świecie... (KW 227) ${ }^{12}$.

Jak widać, autor nie obawia się konsekwencji wynikających ze stawiania tak odważnych tez. Ale oddajmy choć na chwilę głos komuś, kto nie jest tak wytrawnym amatorem wina. Oto zespół kierowany przez profesor Ann Noble zapisał się w historii typologizowania zapachów wina dzięki opublikowanej w 1984 roku idei "Koła Aromatycznego”, które wyglądem przypomina tarczę do gry $\mathrm{w}$ darta . Przedstawia ono ustandaryzowaną terminologię opisującą aromat wina: dwanaście kategorii i dziewięćdziesiąt cztery terminy opisowe pozwalające - w intencji autorów - na określenie każdego [podkr. M.G.] aromatu wina niezależnie od gatunku winogron czy regionu pochodzenia ${ }^{13}$. Jak pisze autor książki "Co wnosi

12 Podobnie, na stronie Portal wina, wypowiada się autor wpisu o historii winiarstwa w Polsce: „Większość dawnych win, a przynajmniej te, które upodobali sobie Polacy to wina słodkie. Polski gust, ukształtowany przez znane od setek lat miody, niezbyt chętnie dostosowywał się do podbijających Europę win wytrawnych. Stąd małmazja i petercyment cenione były znacznie wyżej niż doskonałe wina burgundzkie czy bordoskie. A przecież to nie wszystko. Do słodkich win należały również bardzo popularne wina z wysp kanaryjskich tak zwane kanary lub seki, pochodzący z południa Hiszpanii alikant, a przede wszystkim węgierski maślacz." źródło: http://www.winomania.pl/wino_w_polsce [dostęp: 30.06.2016].

13 Na marginesie dopowiedzmy, że świadome pomijanie tych faktów zapewne nie śniło się winnym koneserom. Ale ignorowane są też i inne okoliczności spotkania z winem, np. 
nos? Nauka o tym, co nam pachnie" 14: „Wąchając wina z pomocą Koła Aromatycznego, można doznać zmysłowego oświecenia. To zdroworozsądkowe podejście pozwala każdemu zrozumieć umieszczoną w środku koła kategorię mikrobiologiczne i jej zagadkową podkategorię mleczne. W pewnej chwili jesteśmy zdezorientowani, ale gdy tylko powąchamy przykładowe próbki - jogurt i kiszoną kapustę - nagle wszystko staje się jasne. Koło Aromatyczne pozwala nawet rozszyfrować termin mokry pies, którym posługują się winiarskie snoby: a jest to po prostu jeden z odcieni zapachowych siarki z kategorii chemiczne (razem ze skunksem, kapustą i spaloną zapałką). W Kole Aromatycznym nie ma miejsca dla enigmatycznych przymiotników, w jakich lubują się specjaliści. Znajdziecie w nim kwiat pomarańczy i czarną oliwkę oraz mniej pochlebne: mydlany czy gotowana kapusta, ale nie mały impertynencki pinot noir czy anemiczny, przejrzały cabernet franc á la Miles Raymond [...]. Te poetyckie nazwy więcej mówią o pretensjonalności miłośnika wina niż o charakterze samego trunku. Żeby skorzystać z Koła Aromatycznego potrzebny jest jedynie kieliszek i sklep spożywczy".

Przywołane badania prowadzone były na Uniwersytecie Kalifornijskim w Davis, a ich celem, poza sensoryczną analizą wina, było zastosowanie obiektywnych metod do opisu skrajnie subiektywnych wrażeń towarzyszących degustacji wina. Jak można przypuszczać, ustalenia amerykańskich badaczy nie zyskały aprobaty europejskich winiarzy, podobnie jak produkowane w Kaliforni wino. Co więcej, także w enologicznej terminologii pojawiło się pojęcie kalifornizacji, czyli winiarskiej mcdonaldyzacji, definiowanej jako „zjawisko ujednolicenia potrzeb konsumentów, będące efektem globalizacji i rozpowszechnienia kultury masowej. Proces ten objął także kulturę winiarską, powodując usilne próby winiarzy, mające na celu upodobnienie swoich produktów do najbardziej popularnych na rynku win"15. Nie zyskało aprobaty również dlatego, że - poza warunkami, w jakich produkowane i przechowywane jest wino, osobą degustatora i okolicznościami w których następuje jego spotkanie z trunkiem, istotną rolę odgrywa ono samo. A jak pisze Marek Bieńczyk:

dotyczące jego transportu i przechowywania. Tymczasem, jak podkreśla jeden ze znawców wina: „Podobnie jak zmian temperatury, wino nie znosi drgań, wibracji i hałasu” żródło: http://www.winomania.pl/porady.php? [dostęp: 30.06.2016].

14 http://www.literatura.gildia.pl/tworcy/avery_gilbert/co_wnosi_nos_nauka_o_tym_co_ nam_pachnie [dostęp: 30.06.2016].

15 http://www.owinie.info/slownik-pojec/ 
Każde niemal wino ma swoje kaprysy, swoje nastroje, lepsze i gorsze dni. [...]

Dlatego picie wina jest spotkaniem z nieznanym [...] (KW 247-8)

oraz:

[wino] rozwija się [...] jak akcja [...], aż do swej kulminacji, z upływem czasu zmienia wciąż swą treść, otwiera się powoli, by wreszcie odkryć wszystkie swoje tajniki [...] (KW 286-7).

Co ważne - przed każdym wino odkrywa się w inny sposób, co opisać można wyłącznie z wyzyskaniem wzorców gatunkowych felietonu. Przywołane fragmenty w doskonały sposób uwidaczniają, że główną cechą analizowanych tekstów jest nie tylko ich tematyka16, ale postać autora, który nie tylko sprawnie posługuje się enologicznym socjolektem, ale jest też - na co, jako na istotną cechę gatunku wskazuje M. Wojtak (Wojtak 2008: 110) - artystą słowa wykorzystującym język w kreowaniu swego własnego świata, stawiającym czytelnikowi prowokacyjne, często retoryczne pytania, niekiedy nawet narzucającym mu subiektywną wizję opisywanej rzeczywistości, wykorzystującym w tym celu zarówno stereotyp, jak i językową prowokację (jak choćby w przywoływanej wyżej wizji warszawskiej kawalerki i jej właściciela). Wszystkie te zabiegi - oprócz autokreacji - służą aktywizacji czytelnika, są swoistym zaproszeniem go do - pozornie niedostępnego - kręgu winnych koneserów. Odpowiadając więc na stawiane we wstępie do obu tomów pytanie "dlaczego wino", spośród wielu odpowiedzi znajdziemy i tę, mówiącą o niemożliwym do zrealizowania pragnieniu odkrycia winnego sekretu:

Dlaczego więc wino, pytać będzie trzeba dalej i przesyłać pytanie w nowe dni, kolejne dekady, nadchodzącą erę, aż umilknie kiedyś na brzegu wieczności. Pytanie o tajemnicę wina stawiali wszyscy, którzy w dziejach poczuli się tak czy inaczej nią muśnięci; poczuli ten dotyk, usiłowali o nim zaświadczyć, i ich opowieści składają się na niekończącą się historię wina (NKW 5).

\section{SKRÓTY}

KW - Bieńczyk M, 2001, Kroniki wina, Warszawa

NKW - M. Bieńczyk M. 2012, Nowe kroniki wina, wyd. 2., Warszawa

SJP - Słownik języka polskiego red. W. Doroszewski, Warszawa

16 Zresztą felieton może być na każdy temat i wielu badaczy uznaje tematykę za cechę nieistotną, zob. A. Barańska-Szmitko, op. cit. 


\section{LITERATURA}

Barańska-Szmitko A., 2014, Możlizwości i ograniczenia felietonu jako narzędzia kreowania wizerunku jego autora, „Acta Universitatis Lodziensis. Folia Litteraria Polonica", 1(23)/2014, s. 211-227; http://cejsh.icm.edu.pl/cejsh/element/ bwmeta1.element.hdl_11089_8986/c/12-baranska.pdf (dostęp: 13.01.2017).

Bárcena E., Wisłocka-Breit B., 2012, La traducción intercultural de lenguajes especializados: el caso del lenguaje enológico, "Studia Iberystyczne”, t. 11., s. 207-219.

Bochnakowa A. 2020, Jak opisać wino?, [w:] Między oryginatem a przekładem, VII: Radość tłumaczenia. Przekład jako wzbogacanie kultury rodzimej, red. M. Filipowicz-Rudek, J. Konieczna-Twardzikowa, Kraków, s. 107-115.

Bugajski M., 2004, Jak pachnie rezeda? Lingwistyczne studium zapachów, Warszawa.

Graf M., Cieliczko M., 2015, Filologia wina - prolegomena, [w:] Język tożsamości. Język. Religia. Tożsamość XI, red. G. Cyran, E. Skorupska-Raczyńska, Gorzów Wielkopolski, s. 21-38.

Herbert Z., 1997, Barbarzyńca w ogrodzie, Wrocław.

Pisarkowa K., 1972, Szkic pola semantycznego zapachów w polszczyźnie, „Język Polski" LII, 1972, nr 5, s. 330-339.

Potargowicz E., 2008, Węch - niedoceniany zmysł człowieka, „Postępy Higieny i Medycyny Doświadczalnej", nr 62, wersja online: http://www.phmd.pl/fulltxt html.php?ICID=834265 [dostęp: 15.03.2014].

Saniewska D., Klejnot na szyi kobiety. O nazwach damskich perfum, http://repozyto rium.uwb.edu.pl/jspui/bitstream/11320/1071/1/BAJ_12_Saniewska.pdf [dostęp: 12.02.2017].

Skrzypczak K., 2013, Metaforyczne wino. Językowe sposoby charakteryzowania cech wina w kontekście lingwistyki kognitywnej, „Conversatoria Linguistica” VII, s. $101-108$.

Wojtak M., 2008, Analiza gatunków prasowych. Podręcznik dla studentów dziennikarstwa $i$ kierunków pokrewnych, Lublin.

Wojtak M., 2004a, Gatunki prasowe, Lublin.

Wojtak M., 2004, W kręgu paradoksów gatunku, czyli o konwencji i kreatywności w felietonie, w: Język polski w perspektywie diachronicznej i synchronicznej, red. K. Maćkowiak, C. Piątkowski, Zielona Góra, s. 273-293.

\section{ŹRÓDŁA INTERNETOWE}

www.owinie.info/slownik-pojec/ (dostęp: 13.01.2017)

http://wino.org.pl/old-swimp/content/view (dostęp: 13.01.2017)

http://festus.pl/slownik (dostęp: 13.01.2017)

http://www.literatura.gildia.pl/tworcy/avery_gilbert/co_wnosi_nos_nauka_o_

tym_co_nam_pachnie (dostęp: 30.06.2016)

http://wiktorzastrozny.com/ (dostęp: 30.06.2016) 
http://kobieta.gazeta.pl/kobieta/1,107881,12940220,senselierka-jak-zostalamjedyna-w-polsce-specjalistka-od-zapachow.html (dostęp: 12.02.2017)

\title{
(NOT)ESSENTIAL CONSIDERATIONS ABOUT WINE ESSENSCE (IN THE MARGIN OF THE MAREK BIEŃCZYK'S OENOLOGICAL COLUMNS)
}

\begin{abstract}
Summary
Zbigniew Herbert in the volume titled Barbarian in the garden said: "The description of the wine is more difficult than the description of the cathedral". The subject of this article is to answer the question, if there is any objective way of describing sensations connected with wine tasting and estimation strategies used by Marek Bieńczyk in his oenological columns to talk about wine. In the first part of the article the most important features of wine discours, methods of linguistics depiction of flavour, the etymologically variety of wine vocabulary and the most important elements of tasting terminology are showed. Hereinafter of the article author's attention is focused on Marek Bienczyk's columns about wine and wine culture (from volumes 'Chronicles of wine' and 'New chronicles of wine'). These texts present not only how complicated is the systematic description of wine, but what is more, show the importance of subjective impressions and individual way to show this using the language.
\end{abstract}

Key words: idiolect, wine, enology, feuilleton 